Environnement urbain

Urban Environment

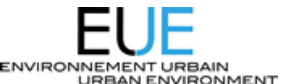

\title{
On The Sustainability Of Urban Institutional Dynamics: Capitalization, Decentralization, And The Case Of Two Alpine Cities
}

\author{
Jon Marco Church et Nicolas Maisetti
}

Volume 5, 2011

Ville durable et changement climatique

Sustainable city and climate change

URI : https://id.erudit.org/iderudit/1005875ar

DOI : https://doi.org/10.7202/1005875ar

Aller au sommaire du numéro

Éditeur(s)

Réseau Villes Régions Monde

ISSN

1916-4645 (numérique)

Découvrir la revue

Citer cet article

Church, J. M. \& Maisetti, N. (2011). On The Sustainability Of Urban Institutional Dynamics: Capitalization, Decentralization, And The Case Of Two Alpine Cities. Environnement urbain / Urban Environment, 5, 24-37.

https://doi.org/10.7202/1005875ar

\section{Résumé de l'article}

L'objet de cet article, qui s'appuie sur une étude comparative des processus de capitalisation - compris comme la transformation d'une localité en chef-lieu et de décentralisation, porte sur la dimension institutionnelle des dynamiques urbaines. Observée dans plusieurs contextes urbains, la concomitance de ces deux processus nous conduit à nous interroger sur le degré de durabilité des configurations spécifiques générées par ces dynamiques. Une exploration mentale des conséquences potentielles de la prédominance de l'une sur l'autre a été menée afin de vérifier cette hypothèse. À partir d'une étude de cas réalisée sur deux villes alpines italiennes - Turin et Bolzano - nous avons recueilli des données empiriques et établi une comparaison entre les deux cadres théoriques. Les résultats des analyses montrent que les processus de capitalisation et de décentralisation trop extrêmes ne favorisent pas la durabilité. Par conséquent, des mesures politiques doivent être prises par les institutions urbaines pour parvenir à contrôler ces processus de sorte à éviter les extrêmes et réduire les problèmes qu'ils entraînent. 


\title{
ON THE SUSTAINABILITY OF URBAN INSTITUTIONAL DYNAMICS: CAPITALIZATION, DECENTRALIZATION, AND The Case Of Two Alpine Cities
}

\author{
Jon Marco CHURCH \\ Nicolas MAISETTI
}

\begin{abstract}
I RÉSUMÉ
L'objet de cet article, qui s'appuie sur une étude comparative des processus de capitalisation - compris comme la transformation d'une localité en chef-lieu - et de décentralisation, porte sur la dimension institutionnelle des dynamiques urbaines. Observée dans plusieurs contextes urbains, la concomitance de ces deux processus nous conduit à nous interroger sur le degré de durabilité des configurations spécifiques générées par ces dynamiques. Une exploration mentale des conséquences potentielles de la prédominance de l'une sur l'autre a été menée afin de vérifier cette hypothèse. À partir d'une étude de cas réalisée sur deux villes alpines italiennes - Turin et Bolzano - nous avons recueilli des données empiriques et établi une comparaison entre les deux cadres théoriques. Les résultats des analyses montrent que les processus de capitalisation et de décentralisation trop extrêmes ne favorisent pas la durabilité. Par conséquent, des mesures politiques doivent être prises par les institutions urbaines pour parvenir à contrôler ces processus de sorte à éviter les extrêmes et réduire les problèmes qu'ils entraînent.
\end{abstract}

MOTS-CLÉS - Institutions urbaines, durabilité, capitalisation, décentralisation, villes alpines

\section{ABSTRACT}

The focus of this article is on the institutional dimension of urban dynamics, particularly on the twin processes of capitalization - defined as the transformation of a place into a capital city - and decentralization. We observe that they co-exist in several urban contexts. A study was conducted addressing the inherent level of sustainability for each configuration produced by the dynamics. This hypothesis was tested by performing a mental experiment to assess the consequences of the prevalence of one dynamic over the other. To do so, a case study was undertaken on two Italian Alpine cities - Turin and Bolzano - in order to empirically ground the experiment and compare the two conceptual models. From our analysis, both extreme centralization and decentralization seem unsustainable. The broader policy implications are clear: urban institutions must seek to control these processes by avoiding the extremes and mitigating their impacts.

KEYWORDS - Urban institutions, sustainability, capitalization, decentralization, Alpine cities

1 Coordonnées de l'auteur : Jon Marco Church, Harvard Kennedy School, Cambridge, MA, USA; email: jonmarco church@hks.harvard.edu. Nicolas Maisetti, Université de Paris I - Panthéon-Sorbonne, Centre Européen de Sociologie et de Recherches Politiques de la Sorbonne, email: nicolas.maisetti@univ-parisl.fr. 


\section{INTRODUCTION}

These days, it is hard to find an Alpine city that does not aspire to become the "capital" of the European Alps: Chambéry and Grenoble in France, Lucerne and Lugano in Switzerland, Turin and Bolzano in Italy, Salzburg and Innsbruck in Austria. The process of selection of the seat of the Permanent Secretariat of the Alpine Convention, a regional environmental agreement, provided for a neat example of this phenomenon'. At first, this does not appear as much of a surprise, since such recognition brings considerable symbolic and economic benefits: more responsibility, more resources, more investment, more industry, more jobs, and more wealth. This article draws on Portuguese historian António Henrique de Oliveira Marques' notion of "capitalization", which refers to the process of transforming a place into a capital ${ }^{2}$. Nation-states and other territorial entities have experienced this process, to the extent that a particular city was chosen or labelled as official capital or chef-lieu. This resulted in the materialization (or "reification") of benefits for the city, including the seat of an effective government, the presence of foreign representatives, the head office of large corporations, the construction of important buildings and squares, etc. However, two major issues surface with capitalization. First, it is hard to assess symbolic and material effects, in part because complex multicausal processes have occurred in the internationalization of cities. Second, it is unclear how this plays out with the process of decentralization, determined by the constant increase in territorial diffusion, which is exemplified by suburbanization and the emergence of urban features in previously rural areas $^{3}$. Over the years, these cities have in fact substantially benefited from the loosening of the monopolies of central governments as a result of both the Europeanization process and the principle of subsidiarity ${ }^{4}$.

The twin movements of capitalization and decentralization are informed by institutional and spatial dynamics. In this article, we emphasize the institutional dimension of the phenomenon. However, this should not be understood merely as a scholarly

\footnotetext{
I See, in particular, the contribution by Irini Papanicolopulu (2004).

${ }^{2}$ See António Henrique de Oliveira Marques (1972). For more references, see infra.

${ }^{3}$ For a critical appraisal of territoriality, always refer infra.

${ }^{4}$ On European cities between decentralization and globalization, see, in particular, Bernard Jouve and Christian Lefèvre (2002). On the subsidiarity principle, see Chantal Millon-Delsol (1993) and, on its influences on environmental politics in the EU, see Regina Axelrod (1994).
}

exercise per se. Our research is conducted with the clear intention of exploring whether a particular configuration produced by such institutional dynamics can lead to sustainable outcomes ${ }^{5}$. This exploration begins with the working hypothesis that the coexistence of capitalization and decentralization is more likely to be sustainable than not. Here, both the socioeconomic and the ecological aspects of sustainability are considered. On the one hand, the legitimate desire for economic development and social justice by current generations must be addressed. This has both a spatial dimension (North versus South, centre versus periphery) and a temporal dimension (present versus future generations). On the other hand, it is vital that these advances do not undermine the right of future generations to a healthy environment, to a planet that can sustain their livelihoods ${ }^{6}$.

To begin testing this hypothesis, we carried out a case study of two Alpine cities. A mental experiment was performed in order to explore, based on the existing literature, what would emerge if either of the two movements were to prevail. This mental experiment, however, is only the first step of a larger research program. Our aim is to contribute to the ongoing debate on the attributes of what Elinor Ostrom calls "governance systems" for sustainability, or institutional frameworks that would be conducive to sustainable livelihoods. From this perspective, this article fits in with the emerging field of "sustainability science", what William Clark defines as "the scholarship, training, and invention that can inform action on sustainable development" (2007, page?) ${ }^{7}$. As far as the case studies of the cities of Turin and Bolzano are concerned, these reflections also contribute to the ongoing debate on the sustainability of the current pattern of development of Alpine cities. There are at least two major networks of Alpine cities and municipalities: Alliance in the Alps and the Network of the Alpine Cities of the Year ${ }^{8}$. Issues relating to sustainability in the Alps regions were considered and

\footnotetext{
${ }^{5}$ For an introduction to sustainable urban development, see François Mancebo (2006).

${ }^{6}$ See, in primis, the report Our Common Future by the Un World Commission On Environment And Development (1987). A reference to the holistic concept of livelihoods, inspired by the Amartya Sen's philosophy, is also relevant. It was launched by the Institute for Development Studies in the UK and became a cornerstone of the work of the UK Department for International Development (DFID), as well as many international organizations and NGOs (Chambers and Conway, 1991).

${ }^{7}$ As well as Ostrom's contribution in the forthcoming book Sustainability Science: An Introduction by Partha Dasgupta et al.

${ }^{8}$ See, for instance, the recent article by Cristina Del Biaggio, presenting the case study of Alliance in the Alps (2009); see also Marie-Christine Fourny et al. (2004).
} 
discussed on several occasions during the past decade?. At the Institute of Alpine Geography in Grenoble, for instance, Paul and Germaine Veyret, Claude Raffestin, and Bernard Debarbieux have turned their attention specifically to Alpine cities and to the role of cities in the production of knowledge on mountainous areas. However, they did not fully explore the dynamics between capitalization and territorial diffusion ${ }^{10}$.

To this end, we begin with an exploration of the institutional dynamics constituted by the movements of capitalization and decentralization, framing this question in a broader scholarly context. We attempt, therefore, to identify the set of issues surrounding territoriality, which we can define as the process through which the territory is known and appropriated over time". Then, in order to test the working hypothesis that the co-existence of capitalization and territorial diffusion is more likely to lead to more sustainable outcomes, a mental experiment is performed on two Alpine cities. We selected the cities of Turin and Bolzano because they are highly representative of both movements, which will become apparent in the discussion presented in the second part of the article. Modernity, postindustrialism, autonomy, and multiculturalism are factors that are relevant to the findings. The city profiles show how they are similar without being identical; they are different, without being incommensurable. Besides, they have been the object of a fair number of studies. Of course, we could have selected other cities like Grenoble or Chambéry. Turin and Bolzano are unique in that they can provide a broader base for the mental experiment, rather than simply for conducting a rigorous comparison or a structured and thorough iterated analysis. The mental experiment therefore involves an inquiry on the consequences of the prevalence of one movement over the other, particularly in the areas of energy use, transportation, tourism, and agriculture. Moreover,

\footnotetext{
9 From the conference "L'avenir des villes des Alpes en Europe", held in Villach, Austria, in 1999 (PERLIK, 1999), to the next Forum Alpinum, the major convention on Alpine research, which meets in Munich, Germany, under the theme "Metropolises and 'Their' Alps". See also the various meetings under the EU INTERREG IIIB AlpCity Project (2003-2006)

${ }^{10}$ With the exception, possibly, of the paper presented by Veronika Keckstein on the case of Kötschach-Mauthen, a municipality of Carinthia (1999)

" On territoriality, see, in primis, the articles "Ecogenèse territoriale et territorialité" by Claude Raffestin (1986), "Of Systems, Boundaries, and Territoriality" by Friedrich Kratochwil (1986), and "Territoriality and Beyond" by John Ruggie (I993); see also the skeptical appraisal by John Agnew (1994), and, for a globalist perspective, Saskia Sassen (2006).
}

the presence of mountains underscores the importance of the environmental dimension, considering - following William Clark - that any human settlement is a coupled human-environment system and - following Ignacy Sachs - that any development is at the same time economic, social, and environmental ${ }^{12}$.

\section{PROBLEMATIZING TERRITORY}

\section{I.I Capitalization}

We call "capitalization" the process whereby a city is transformed into a capital, borrowing the expression from the great historian Oliveira Marques. Exerting territorial leadership on a macro-regional scale is a common target shared by political and business actors. The vagueness that surrounds both this phenomenon and the anthropomorphic concept of territory has lent support to the convergence towards specific strategic orientations, despite the contradictions or the redundancies between different interests. Leadership manifests itself in the constant discourse about being a so-called "capital". The designation of rival cities constitutes another point of entry into this symbolic process of territorial competition. However, the definition of the label "capital" is never established while representations and interpretations of social reality are numerous and varied. When they try to convince institutional organizations to relocate in their city, urban elite make use of this label to claim a status that is the equivalent of the official state capital designation. This is found to be somewhat paradoxical since inter-territorial competition often occurs within non-state spaces. In the case of the Alps, for instance, the capital operates within a transnational and partly imagined space. Taking part in a competition to outdo each other and become the capital of the Alps suggests also that obtaining this title is more than just a symbolic struggle between rivals. It also involves institutional processes. Finally, the process of recognition itself allows us to discuss the main issues related to the multidimensional dynamics of political and economic investment, symbolic and material resources, as well as individual and institutional commitments. These dynamics occur over a large area in order to exert leadership.

\footnotetext{
12 On coupled human-environment systems, see, in particular, the volume The Earth as Transformed by Human Action, edited by B. L. Turner II, William Clark, et al. (1993), as well as the contribution by William Easterling and Colin Polsky (2004), and on eco-sociodevelopment, see Sachs (1997, 2004).
} 
The claim to leadership involves legal, physical, cultural and historical considerations. Before being recognized as a capital, a city must first bring together aspects of material and symbolic culture drawn from the socio-historical background of the city. Consequently, the city can obtain the rank of capital by claiming the title. Such a passive approach and the tautological nature of lay assertions and academic research imply that caution should be used when assuming the rationality of so-called international strategies. These are for the most part a set of separate and disordered actions by different types of actors with incompatible interests, motives and representations. Moreover, some discourses highlight how actors are not mislead by such artefacts and implicitly reject the terminology associated to capitals. At the local level, opposition to the capital label resorts to both tactical and technical methods. The aim is largely to mask ambitions from partners and to express self-effacement and pragmatism in the context of territorial competition, while applying a rigorous approach to leadership. Indeed, when it comes to proposing policies, actors who refuse to fall in the selffulfilling prophecy trap never refer to the terminology associated to capitals. Instead, they try to fulfill their ambitions and meet their goals through the implementation of projects. For instance, these dynamics play a major part in projects for climate change. As climate concerns become increasingly central to the political debate, the initiatives undertaken by big and small cities alike to address this issue is an important component of capitalization strategies. How can a city emerge as a central place if it does not try to deal with important issues?

Questions and criticisms of a similar nature can be raised about the alleged issue of influence (in French, rayonnement). First, actors and researchers both refer to this term: the former to justify their actions, and the latter to describe and explain them. Since the explicit aim of external affairs departments in city councils is to "enlighten and influence", it seems important to be cautious in using lay terms in order not to be constrained to recreate ex-post strategies. Second, it is hard to quantify influence, if we agree to consider it as the will to spread a model, practices, and know-how. Since it is always about interactions, benefits and effects, the nature of influence can be measured in degrees. Thus, leadership and influence draw attention to a form of relation to power and domination. So-called partners try to modify the behaviour of a third person in order to make him or her act according to their desire. Even when the notion of capital is used rhetorically, it is always situated within a competitive market characterized by the inter-urban reproduction of inequalities between territories.

\section{I.2 Territorial Diffusion and Decentralization}

Turin and Bolzano are good examples of the coexistence of the two movements of capitalization and decentralization. As stated in the above discussion, the process of capitalization is eminently modern. It has its historic roots in the expansion of nation-states. Indeed, in early modern times, European sovereigns did not live continuously in a single city. The increase in trade and, consequently, the development of markets and ports, played a critical role in this process, especially since the taxation of these activities led to a concentration of bureaucracy in these places ${ }^{13}$. Following Michel Foucault, the invention of one-point perspective in depicting three-dimensional forms must also have been instrumental in this regard, leading to a sort of "visibility trap" (Foucault, 2004a, 2004b). With their legal basis and mandates, these central cities were able to thrive, were better connected with the rest of the country, and their food supplies became a matter of vital interest. Capitals developed into a "rationalizing" element for each modern nation-state ${ }^{14}$. The process today is similar and aims to concentrate certain activities, including administrative functions, in a particular location and to reduce transaction costs and thus generate economies of scale, which requires that health, transportation, and trade be properly managed.

This illustration provides only half of the picture of what is occurring in cities like Turin and Bolzano. An opposite process of territorial diffusion is also in motion. Indeed, decentralization is understood here as the institutional dimension of territorial diffusion. It is sometimes referred to as "postmodern" with an implicit reference to the very modern process of capitalization $^{15}$. Of course, decentralization can be interpreted as a form of local capitalization. However,

\footnotetext{
${ }^{13}$ On the process of capitalization in modern Spain, see John Elliott's classical Imperial Spain, while on Portugal, besides Oliveira Marques, see António Manuel HESPANHA (1986) and Joaquim Magalhães (1993, p. 52). Similar literature can be found for Renaissance Tuscany, Louis XIV's France, and virtually all European nation-states.

${ }^{14}$ On modernity, see, inter alia, Immanuel Wallerstein (2004), and on post-modernity, see Robert Cooper (2000). On alter-modernity, read Ulrich Beck (1992), while for a provocative take on us "never having been modern", see Bruno Latour (1997).

${ }^{15}$ The English School of international relations would say, instead, “neo-medieval” (Bull, 1977; Gamble, 2007; Hurrell, 1995, p. 45).
} 
by placing the process within the observed phenomenon of territorial diffusion, an alternative interpretation of the process at odds with capitalization is proposed. Political scientists have favoured this interpretation for a long time. In the 1960s, for example, Seymour Lipset and Stein Rokkan defined decentralization as a centre-periphery cleavage "between the central nation building culture and the increasing resistance of the ethnically, linguistically and religious subject population in the provinces" (1967, p. $10)^{16}$. While this tension is historically grounded in the resistance to the centralization process that accompanied nation building, in recent years and in several European countries state induced decentralization is also observed: for instance, in France, with the creation of regions, and in the United Kingdom, with the so-called devolution process of the 1990s. These phenomena generally encountered two opposite views: at one end, Amitai Etzioni sees it as the reemergence of communitarian dynamics (Etzioni, 1993; Tilly, 1998), at the other end, globalists interpret the apparent weakening of the nation-state as "the end of geography" or even "the end of territories", clearly mimicking Francis Fukuyama's "end of history" $(1992)^{17}$. The political significance of this scholarly debate clearly emerges in the literature. The Québécois sovereignists in Canada or the Northern League in Italy are two well-documented cases. Michael Keating offers a more nuanced explanation of this cleavage, explaining this phenomenon in terms of functional pressures converging on national institutions struggling with the welfare state, and local movements seeking political autonomy, which ultimately lead to a renewed form of territoriality.

From this perspective, inter-regional and inter-city rivalry replaced inter-state competition ${ }^{18}$. Financial trade and resource accumulation activities locate mostly in major cities. Moreover, globalization is often described as a process of state restructuring and even of decline. From this viewpoint, the allocation of power among political units would favour supra-

\footnotetext{
${ }^{16}$ In the 1970s, a centre-periphery model applied to international relations contributed to the development of so-called dependency theory: if the structure of the world system follows those lines, economic development can then be understood as the tension between countries at the centre and those at the periphery, based on their position in the system (Cardoso and Faletto, 1984; Wallerstein, 1974, 1980). The same model could be applied at both macro and micro scales, including cities (Knox and Taylor, 1995).

${ }^{17}$ As argued in Richard O'Brien (1992) and, more strongly, in Bertrand Badie (1995). See again Jouve and Lefèvre (2002).

${ }^{18}$ On the new power of regions in the global economy, see Ash Amin (2002); Allen Scott (1998); Hank Savitch and Paul Kantor (2002); Pierre Veltz (2008).
}

national and sub-national entities over the state ${ }^{19}$. The theoretical framework of "urban governance" argues that re-territorialization processes are a constituent part of the current phase of globalization (Brenner, 1998) This premise forms the basis for a sociology of place, that identifies territory as an important component of global change (Agnew and Duncan, 1989). According to Manuel Castells, globalization refers to "flow economy" disarticulated, social interaction and territorial attachment (Castells, 2002). Here, the de-territorialization of accumulation regimes rests on a conception of transnational relations that abolishes distance and space. Globalization processes are viewed as devices for mobility of individual, goods, capital, and identity ${ }^{20}$.

However, these analyses neglect the fixed forms of territorial organizations, such as urban agglomerations as well as institutions and networks that make exchanges possible. For David Harvey, territory is a relevant spatial form for global regulation. Following the work of Henri Lefebvre, he reflects on urban governance issues and argues that such organizations provide renewed opportunities for local practices geared towards the growth of the local employment market (Lefebvre, 1974). Interurban competition is therefore the result of macro-economic dynamics occurring at the regional scale (Harvey, 1989). Harvey identified strong links between local governance variation and the global economic context. The city still provides an entry point, the source and territorial destination of economic and technological flows of goods and services as well as cultural and political flows of information and values. Territory is the "spatial fix" of capital and ideas, a space for negotiations where they can be established and restored. A pre-requisite for their accumulation and diffusion is the existence of spatial organizations to the same extent as state regulation. Global transformations imply that the state is losing its influence and hollowing out. Nevertheless, the state does not lose its ability to project power despite the transfers of sovereignty toward supra and infra-national institutions, public and private actors. These structural changes affected by and affecting global economy are the result of these transfers. The crucial issue here is the re-articulation of the political capacity of traditional and new units, what Brenner calls the

\footnotetext{
${ }^{19}$ The literature on the supposed retreat of the state is too abundant to be discussed here in detail. See the seminal work by Susan Strange (1996) (who uses a pseudonym), as well as the perspective on "glocalization" and "state rescaling" by Brenner (1998).

${ }^{20}$ Ruggie (1993); Konichi (1993); on Identity, see Appadurai (1996) and Scholte (2000).
} 
political process of "rescaling". The very same question is addressed in the cases of Turin and Bolzano.

Since the end of the 1940s, the now Autonomous Province of Bolzano benefited from a great degree of political leeway; a similar point can be made about the decentralization process of the Italian state and the creation of the regions in the 1970s. However, what is at stake here are not only alternative centres of production of territoriality: the national capitals, on the one hand, and the Alpine cities, on the other, but also its mode of production. In the case of Bolzano, decentralization is in fact not only the substitution of national centres with regional ones, but also the diffusion of activities on the entire territory outside of the centre, a phenomenon that is sometimes referred to as polycentric development. This process of diffusion generates a dynamism that empowers the whole territory, instead of draining the centre. Territorial diffusion is an alternative manner of appraising a space and appropriating a territory by its inhabitants and is greatly facilitated by the IT revolution $^{21}$. In addition, the Alps have the opportunity to become, through this process, more than a simple backdrop for postcards (Debarbieux, 1999).

\section{EXPLORING TWO ALPINE CITIES}

Before venturing into a presentation of the two case studies, it may be useful to briefly recall the Italian context with particular attention to the Alpine regions $^{22}$. After unification 150 years ago, Italy, following the French model, evolved under a centralizing state for decades. However, a process of decentralization and of Europeanization, which emerged in the 1970s, is characterized by tendency towards federalism. At the beginning of the 1990s when corruption scandals were exposed new political figures and movements surfaced, such as the Milanese entrepreneur Silvio Berlusconi, the post-fascists and the post-communists. In the northern part of the country, we also observe the emergence of the Northern League, a pro-independence movement centred on the Po Plain (Padania) through which flow the rivers originating mainly from the Alps. The region includes small and medium sized Alpine cities, such as Bolzano, Sondrio, and Belluno, and several large cities, such as Turin, Milan, and Verona, which extend into

\footnotetext{
${ }^{21}$ See, in particular, Manuel Castells (2000) and the proposal of "polycentric urban regions" by Giuseppe Dematteis, 2009). The concepts of monocentric and polycentric development are the focal points of the European spatial policy debate.

${ }^{22}$ The main source for these remarks is the German geographer Werner Bätzing (2005).
}

the foothills. Hit by a demographic crisis, the Western and Eastern Alps have seen their population decrease and some settlements have been abandoned. The Central Alps, in contrast, are benefiting from a positive demographic trend, due in particular to the suburban extension of Milan and to a complex series of factors along the Adige Valley, where Bolzano is located ${ }^{23}$.

The Western and Central Alps are subdivided in four regions - Liguria, Piedmont, the Aosta Valley, and Lombardy - plus the two autonomous provinces of Trento and Bolzano. In the late 1940s, Liguria, Piedmont, the Aosta Valley and the Friuli (Venezia Giulia), were each granted the status of an autonomous region, in part because of the presence of significant German, French and Slovene linguistic minorities. The 1970s saw the rise of secessionist movements that have inspired terrorist attacks in the Bolzano Autonomous Province (Südtyrol/Alto Adige). Diversity is an essential trait of the Italian Alps: alongside industrial development, which is considerable in some areas, it is possible to find mass tourism sites like in France, as well as places that managed to preserve their traditional character, especially by preserving their agricultural heritage. Regional disparities are very high, especially between Alpine provinces with moderate levels of income and the autonomous regions with higher living standards. Although the trend is relatively recent, in fact, these were historically poor areas.

\section{I Turin, First Capital of the Kingdom of Italy and Host of the 2006 Winter Olympic Games}

Turin represents both the model of a modern capital and of an Alpine city aspiring to the role of capital of the Alps ${ }^{24}$. It is located in northwestern Italy, not far from the French and Swiss borders. It is situated on a fertile plain and is surrounded by the Western Alps. It is home to the industrial empire, FIAT, and abounds with small and large enterprises in its industrial base as well as from outside, such as coffeemaker Lavazza or IT Olivetti. It hosts large financial institutions like Intesa Sanpaolo and prestigious universities, including the oldest polytechnic established in the country. It is an important and well-connected transport hub, with a highway system, a railway station that serves as a

\footnotetext{
${ }^{23}$ See infra.

24 The three main references on Turin are taken from Giuseppe Dematteis "Città per le Alpi" (I97I), Maurizio Maggi and Stefano Piperno, "Turin: The Vain Search for Gargantua" (2002) and Claude Raffestin, "Turin ou la capitale paradoxale" (2003).
} 
terminal stop, and an international airport. At the administrative level, Turin acts as the chef-lieu of the Piedmont Region, concentrating important functions. Turin possesses all the main qualities of a modern capital, such as Paris, Berlin, Madrid, or London.

In fact, starting in 1713, Turin was the capital of the Kingdom of Sardinia and, between 186I and 1865, it briefly held the title of first capital of united Italy ${ }^{25}$. During this century and a half, the city experienced a period of expansion. The royal family of Savoy aspired to give it grand boulevards, squares, buildings, and castles, like Piazza San Carlo and the Venaria Reale, which were built by avant-garde architects Guarino Guarini and Filippo Juvarra. In its attempt to gain recognition in the rest of Europe, the kingdom adhered to the same principles and goals: more attractiveness, greater wealth, higher status. Turin and its monuments became the showcase of the kingdom. Most administrative functions were concentrated in the capital, which was progressively reorganized in a manner that guaranteed their proper accomplishment: providing a safe and clean environment for the court and their guests (Foucault, 2004a, 2004b) and promoting the development of intensive agriculture and start-up industries in its surroundings, which was tailored to meet the interests of Piedmontese aristocracy and higher bourgeoisie. The burgeoning city became the epicentre of the kingdom and it was of vital importance that it could easily be defended not only from external threats but also from internal rebellions. Turin was a rather typical, although relatively small, European capital. Today, political actors in Turin skilfully use the history of their city to assert its political significance and centrality. Similar arguments are used when defending the climate policy. For instance, urban regeneration programs, often funded by the European Investment Bank (EIB), normally involve the construction of environmentally friendly neighbourhoods, especially in seeking new ways to improve energy efficiency ${ }^{26}$.

Since then after losing much of its "mojo", Turin is on the decline. It remains, however, a paramount modern centre of industry, bureaucracy, and rail transportation. The hosting of the 2006 Winter Olympic Games was yet another manifestation of its

\footnotetext{
${ }^{25}$ On the history of Turin, read Valerio Castronovo and Angelo d'Orsi (1987) or Giuseppe Sergi (1997).

${ }^{26}$ We are grateful to François MANCEBO for his contribution in this regard.
}

character $^{27}$. Is there anything more modern than the Olympic Games, where each athlete defends their country and each country stands on equal footing, sublimating modern warfare with "Olympic Peace"? And is there anything more Alpine than Winter Sports ${ }^{28}$ ? By submitting a proposal to host the 2006 Winter Olympic Games, Turin was not only providing a public good and boosting its regional economy, mainly thanks to investment in infrastructure, income from tourism, and improved image, it gave itself the opportunity to assert, once again, its role as the capital of the Alps. Improving the image of the city is at the core of urban boosterism. The internationalization of cities depends on the creation of favourable conditions to facilitate the arrival and integration of urban functions. A bad reputation can hinder the efforts to create such conditions. City product and branding tools for territorial marketing are endorsed by authorities and rigorously implemented. According to Christian Le Bart, "image policy rests on the fiction of consistent political projects, composed of a series of tactical moves that give the appearance of a strategy" (Le Bart, 1999, p. 42I $)^{29}$. However, the city is not for sale at any cost since producers, suppliers, cocontractors or sub-contractors are entrenched in a complex web of political and social interdependencies. The burden of having a plurality of local actors is reduced by pooling incentives as the Torino Internazionale platform suggests (Pinson, 2009). Pooling resources does not resolve the issue of fragmentation, but provides a mise-en-scène of a united front that is fictional and instrumental. The goal pursued by territorial marketing is to confer to the city an alleged unique territorial brand, thus establishing a recognized image and visibility. This set of policies is largely intersubjective in nature because the city image is conditioned by external representations beyond local control. Such politics of recognition try to create a more attractive identity and city image. "Selling the city" means "changing its image". The official logo used in marketing should be easily recognizable in order to make local actors feel part of the diffusion process, and to meet potential investors' expectations.

\footnotetext{
${ }^{27}$ On the 2006 Turin Winter Olympic Games, see Caratti Di Valfrei and Lanzetta (2006), Martina (2006), or Bondonio (2007), while for a social science perspective on the Olympic Games in general, see Toohey and Veal (2000).

${ }^{28}$ In the Alps, Chamonix hosted the first games in 1924, Saint Moritz in 1928 and 1948, Garmisch in 1936, Cortina in 1956, Innsbruck in 1964 and 1976, Grenoble in 1968, Albertville in 1992 and finally Turin in 2006. The Alps hosted ten out of 21 editions (48\%).

${ }^{29}$ Translation is ours.
} 
Local actors face the challenge of finding common sense labels that work well with the brand. The process of establishing a visual identity, understood as a policy narrative and an image improvement campaign, should be committed to meeting specific criteria for content. Instrumental factors do not account for the actual mechanisms that underlie the process. On the contrary, the mechanisms must reflect the current social reality. They should not be too far from common sense, or too near to stigmatizing social stereotypes. The territorial brand is supposed to combine contrasting realities and temporalities: on the one hand, it has a decisive influence on the present; on the other, it has to remain valid in the future. An international city strategy is intrinsically related to the redefinition of territory. Conflicts occur when political and social reality contrasts sharply with appearances. Political and economic actors must negotiate the terms of territorial exchange. As the interviews with local representatives, civil servants and business leaders show, the image is key and the restoration of reputation is decisive in the success or failure of international activities. Territorial attractiveness is only partly the direct result of political will and objective data assessed without difficulty by external investors. Instead, it is mostly the product of intangible perceptions. Consequently, the impact of political initiatives is unpredictable. This uncertainty is all the more reason why firms which are attracted to a certain place and decide to locate there justify their preferences by using a wealth of words, either rational or emotional, to describe their motivations for supporting their decisions.

\subsection{Bolzano, Seat of the Permanent Secretariat of the Alpine Convention and 2009 Alpine City of the Year}

Bolzano is situated in the heart of the Alps, but its pastoral environment gives the wrong impression: in fact, the city flourishes on a mix of service industry (tourism, research, etc.) and intensive agriculture (apple orchards, vineries, etc.). It appears to be a normal chef-lieu of an Italian province located on the strategic transport corridor between Italy and Germany. However, to a certain extent, its positive demographic trend and active territorial branding distinguish it from other cities ${ }^{30}$. Arguably, the most

\footnotetext{
${ }^{30}$ According to the Provincial Statistical Office, in the third trimester of $2008,78 \%$ of the population was active in the service sector and, in 2007, the demographic trend was $1.28 \%$. For an example of territorial branding, see the official portal of South Tyro: www.altoadige.info (last accessed: April 29, 20II). On the crossing of the Alps, see Bernard Debarbieux (2002).
}

singular aspect of Bolzano is the coexistence of three cultures in the same territory (German, Italian, and Ladin). This situation led to innovative strategies, such as the choice of trilingualism (English, Italian, and German) for the European Academy of Bolzano (EURAC), an innovative applied research centre created in 1992, and the Free University of Bolzano created in 1997, which includes branches in Brixen and Bruneck. These characteristics were reinforced by the high degree of political autonomy of the provincial government, and the special treatment enjoyed by alpine regions thanks to the Italian Constitution and EU policies for regional development, which ensures high levels of public investment ${ }^{31}$.

The authorities of Bolzano, due to its economic success, often present themselves as a model for urban development, leading several initiatives at the international leve ${ }^{32}$. The city served twice, in 1995 and again in 2002, as the seat of the Permanent Secretariat of the Alpine Convention ${ }^{33}$. This represents one of the most significant attempts by the city to become the capital of the Alps. The Secretariat provides an important support function for the Convention, and the choice of the seat was certainly strategic. Bolzano for Italy, Grenoble for France, Innsbruck for Austria, Lugano for Switzerland, and Munich for Germany were all candidate cities. After strenuous negotiations, the Contracting Parties selected the cities of Innsbruck and Bolzano, along the dividing line between Germanic and Latin Europe, to be host cities for the Convention. The roles assigned to Bolzano were based on its strengths: the bilingualism of its local institutions, the dynamism of its research and innovation complex, and its location within EURAC ${ }^{34}$. In sum, the choice of

\footnotetext{
${ }^{31}$ On its political autonomy, see, in particular, the 1946 De GasperiGruber Agreement and the 1972 Trentino-Alto Adige Region Special Statute. Pursuant to Article 44(2) of the 1948 Italian Constitution, "the law makes provisions in favour of mountain areas". See also the 1994 Mountain Law (Legge 3 I gennaio 1994, $n^{\circ}$ 97). On the early phases of European policies for regional development, see, for instance, Talbot (1977), and the report The European Community and Its Regions: 10 Years of Community Regional Policy... by the European Communities (1985).

${ }^{32}$ For example, Bolzano actively participates in virtually all networks of local governments at all levels; it supports the development of a EU green paper on mountain policy (the President of the Autonomous Province of Bolzano, Luis Durnwalder, acted as rapporteur in 2008); it also provides development aid to a hospital in Gulu, Uganda.

${ }^{33}$ For this section, the main reference is the unpublished work by Jon Marco Church and Paolo Angelini, "Bolzano e la Convenzione delle Alpi”. See also the special insert to EURAC's journal Academia (Coluccia, 2003).

${ }^{34}$ See Decision VII/2 of the Alpine Conference (2002), especially on the functions assigned to each seat of the Permanent Secretariat.
} 
Bolzano for the seat of the Permanent Secretariat of the Alpine Convention solidifies its claim as the capital of the Alps.

Bolzano's status was recognized when it was named the 2009 Alpine City of the Year. The award was assigned by an international jury to express its appreciation for the city's commitment in pursuing the mandate of the Alpine Convention, especially in the field of environmental protection and sustainable development $\mathrm{t}^{35}$. The jury justified its nomination by highlighting the remarkable work Bolzano has accomplished in the fight against climate change. In this regard, regional planning played a key role: in fact, since 2004, the city developed a "Strategic Development Plan", in the framework of a EU project; in 2005, the province approved an "Air Quality Plan"; and, recently, the city adopted a "Climate Pact", aiming at making Bolzano climate neutral by $2020^{36}$. The consequences of global warming, particularly melting glaciers, pose important risks to the regional economy, which is highly dependent on the tourism sector. The Alps are a symbol of mountains all over the world, and this award honoured Bolzano as their "spiritual" capital for 2009.

Marxist interpretations of territorial competition could also be helpful in studying the cases of Turin and Bolzano. Each historical phase of capitalism can be characterized by specific geographies, which in turn can influence local decision-making processes. Urbanization, social change, and economic regulation i.e. city re-production dynamics - vary according to the patterns of capital accumulation at the global scale. Following the hypothesis of the transition from a Fordist to a Keynesian model and later to a flexible form of capital accumulation in the 1970s, Turin and Bolzano can be conceived as ideal-types of adaptation to this transition. Robert Jessop considers the "terminal decline" of the welfare state as the starting point for a new accumulation and regulation regime, which he names the "Schumpeterian workfare state" (JESSOP, 1993).

From his perspective, the Keynesian model was a structural element of post-war economic growth. It contributed to ensure full employment and to

\footnotetext{
${ }^{35}$ The prize was launched in 1997 and its jury is composed by representatives of CIPRA (International Commission for the Protection of the Alps), an influential environmental NGO, of the Pro Vita Alpina society, and of the Alpine Cities of the Year Association.

${ }^{36}$ The pact was presented on April 2-3, 2009, at the conference "Cool Heads in the Hothouse!" and was established under EURAC, adopted by the Municipality, and supported by CIPRA.
}

globalize norms of mass consumption as well as social protection. Since the 1970s, however, it was unable to face the supply crisis and its consequences for the job market. Moreover, it sparked off radical opposition from the New Right that became in the 1980s the political and economic majority, both in the US and the UK. The subsequent Schumpetarian model is structured around innovation in an increasingly open economy. Faced with high levels of competition, policies were oriented towards markets. The nature of capital was altered as commercial then industrial capitalism were replaced by financial capitalism. The growing volatility of capital and the strengthening of the allegiance between private firms and the state have set the stage for the rise of financial capitalism. From this perspective, the economic regime has entered a post-Fordist era. Supply, flexibility, innovation, and competition define the current structures (Amin, 1994). Technological innovations are seen as a crucial factor for change in local government. Indeed, the new regime has turned out to be favourable for newcomers, such as global firms as well as supra and sub-national entities. Consequently, it has shaped a new map of transnational economic networks. In addition, with the introduction of European regulations, the state will have to face increased economic and political competition in the coming years.

\section{CONCLUDING REMARKS: FROM PERFORMING A MENTAL EXPERIMENT TO FURTHER HYPOTHESES}

In this article, we set out to explore the case of the two Alpine cities of Turin and Bolzano. The ensuing discussion enabled us to problematize territoriality by emphasising the twin processes of capitalization and decentralization. We will now further explore the sustainability of these processes, reflecting on the consequences of the prevalence of one movement over the other. A tension seems to exist between these movements. We end with questions for further discussion and research.

Turin and Bolzano are both simultaneously experiencing the processes of capitalization and decentralization and this fact raises critical issues. Do such institutional dynamics lead to sustainable outcomes? In this final section, this set of issues is addressed by performing a mental experiment that is based on the case of the two Alpine cities. To do, the following question is raised: What would the consequences of one process prevailing over the other be for the sustainable development of these urban environments? Work undertaken as part of the Alpine 
Convention provide the basis for the following reflections ${ }^{37}$. The discussion focuses on the one hand on localized activities, such as tourism and agriculture, and on the other hand on networked flows, such as energy and transport. The existence of a major mountain range contributes to the importance of the environmental dimension. This coupled humanenvironment system implies that any development is at the same time economic, social, and environmental ${ }^{38}$.

If the process of capitalization were to prevail, a monocentric spatial dynamic would dominate in the end. In this scenario, economic and administrative activities would tend to accumulate in the capital. Tourism, for instance, would be concentrated in the city at the expense of smaller centres or more remote areas. The relationship between an Alpine city and a ski resort may be similar to that of Paris and Euro Disney. In this particular case, tourist services development in the region would therefore require greater planning efforts, while intensive agriculture at the doorstep of the city could be promoted to reduce reliance on imported products. Arguably, limiting human activities to a small area would reduce energy consumption, for example, for heating or transport and would help streamline management of the power grid. However, this could require the transportation of massive amounts of power from other locations and apparent sustainability would thus be imported (Clayton and Radcliffe, 1996; Mancebo, 2007). While distances between the capital and other major cities would decrease, the transportation network may have an opposite effect on smaller centers like in the case of the French $\mathrm{TGV}^{39}$. The convergence of transport flows towards a single node would increase the likelihood of bottlenecks, which cause traffic disruptions. This is particularly true for European cities, such as Turin or Bolzano, where the urban

\footnotetext{
${ }^{37}$ On transport, refer to the first volume of the Report on the State of the Alps (2007) and, under the cost heading, to the report of the Alpine Convention (2007), while on agriculture, see the specific publication by Austria (2007), as well as Werner BÄTZING (1996). On tourism, refer again to the transport group of the Alpine Convention (2008, 2009a, 2009b), and, to the outstanding piece by Bernard Debarbieux (1995) and the recent article by Andrea Macchiavelli (2009). On energy, besides the implementing protocols to the Alpine Convention, read also the provocative section of Wired ("Inconvenient Truths: Get Ready to Rethink What it Means to be Green", 2008).

${ }^{38}$ See supra.

${ }^{39}$ In 2006, the headquarters of the Alpine Network of Protected Areas (ALPARC) were moved from Gap to Chambéry, France, in part because it takes less than three hours to reach Chambéry from Paris, while it takes more than two hours from Gap to reach Grenoble, which is another three hours away from Paris. On ALPARC, see again Cristina Del Biaggio (2009).
}

fabric is particularly dense ${ }^{40}$. Clearly, the effects of sustainability on the prevalence of the process of capitalization can be called into question.

If the alternative process of extreme decentralization and diffuse territoriality was instead to prevail, referring to the examples in the previous paragraph, economic and administrative activities would scatter over vast areas. Tourism would face the same problem, making the planning of tourist services virtually impossible. This would represent a great increase at the regional level in the degree of anthropization. Agriculture would encroach on previously natural areas, posing a threat to ecosystem conservation. Certainly, the conversion of large areas by human action and the subsequent diffusion of human activities would accelerate energy demands, especially for heating isolated houses and transporting passengers and products over longer distances. While this diffusion may reduce bottlenecks, managing a constantly expanding private and public transportation networks would be difficult if not impossible. While this brings to mind images of the typical American city, the urban phenomenon we are describing here is more radical. Again, the sustainability of the process of decentralization can be called into question.

It can be argued with certainty that the likelihood that either of the two ideal-typical cases takes on such an extreme form is highly remote. Any real development will most probably take place at some point on the imaginary continuum between the two extremes of capitalization and decentralization. Drawing on the "balanced double usage" of Alpine cities proposed by Werner Bätzing, this article therefore is not suggesting that one extreme is sustainable while the other is not. It is even distancing itself from a via media (Bätzing et al., 1996; Perlik, 1999, 2004). Rather, by attempting to single out the institutional dimension and examining it terms of a coupled human-environmental system from an ecosocial-environmental perspective, the article hypothesizes that there may be particular configurations relatively more conducive to sustainable outcomes. There may in fact exist at least one or even several point in this continuum that can be more sustainable than others. These points may also vary according to the context.

More research is needed to help further understand which outcomes and which contexts are more likely to combine sustainable urban development with territorial diffusion and decentralization in the

\footnotetext{
${ }^{40}$ In this regard, see also the work of Gian Paolo Torricelli (1993, 1998).
} 
wake of inter-territorial competition and pressure towards capitalization. Researchers can consider three specific kinds of contexts and outcomes at the micro, meso, and macro-sociological levels. First, the establishment of local business elite could offer a fertile ground to observe the process of creativity under the so-called conditions of postmodernity ${ }^{41}$. Culture-based growth could be closely linked with environmental concerns, since supporters of these causes share common interests and attitudes towards urban development. Second, political arrangements are another contextual feature to take into account. Political leadership, whether strong or fragile, stable or fragmented, could inform the way local authorities cope with capitalization and decentralization dynamics. Third, the growth patterns at the metropolitan level have deeply modified economic and political exchanges that extend across a larger territorial area. Decentralization and capitalization dynamics have driven new forms of territorial bargaining, which centres on the "rival-associate" axis at the regional level (Mabileau, 1995). The move away from centerperiphery interactions toward inter-territorial relations has disrupted political agendas, but it is too soon to tell if this process of change will bring significant benefits to sustainability.

A mental experiment was performed in order to begin testing the hypothesis by assessing the consequences of the prevalence of one dynamic over the other. The empirical analysis presented in this article suggests that both extreme centralization and decentralization are unsustainable. The broader policy implications of these findings call for urban institutions to keep these processes under control by avoiding extremes and mitigating their impacts.

\section{ACKNOWLEDGEMENTS}

This research was partially conducted while Jon Marco Church was a Ruffolo Fellow in the Sustainability Science Program at Harvard University's Center for International Development. Support of CID and the Italian Ministry for Land, Environment and Sea is gratefully acknowledged. The authors would also like to acknowledge the constructive comments of the anonymous reviewers, to whom they would like to express their sincere gratitude.

\footnotetext{
${ }^{41}$ On the English case, see Bassett (1996). On postmodernity, see supra.
}

\section{BIBLIOGRAPHY}

AGNEW, J. (1994). "The Territorial Trap: The Geographical Assumptions of International Relations Theory", Review of International Political Economy, vol. I, no. I, p. 53-80.

AGNEW, J. and J. DUNCAN (1989). The Power of Place Bringing: Together Geographical and Sociological Imaginations, London, Unwin Hyman, 272 p.

AMIN, A. (2002). "Spatialies of Globalization", Environment and Planning C, vol. 34, no. 3, p. 385-399.

AMIN, A. and N. THRIFT (1994). Globalization, Institutions and Regional Development, Oxford, Oxford University Press, $288 \mathrm{p}$.

APPADURAI, A. (1996). Modernity at Large: Cultural Dimensions of Globalization, Mineapolis, University of Minesota Press, 229 p.

AUSTRIA. Bundesministerium Für Land-Und Forstwirtschaft Umwelt Und Wasserwirtschaft (2007). Agriculture de montagne et espace rural, Wien, Österreicher Präsidentschaft der Alpenkonvention, $42 \mathrm{p}$.

AXELROD, R. (1994). "Subsidiarity and Environmental Policy in the European Community", International Environmental Affairs, vol. 6, no. 2, p. II5-132.

BADIE, B. (1995). La fin des territoires: essai sur le désordre international et sur l'utilité sociale du respect, Paris, Fayard, $276 \mathrm{p}$.

BASSET, K. (1996). "Partnerships, Business Elites and Urban Politics: New forms of Governance in an English City?", Urban Studies, April, vol. 33, no. (3), p. 539-555.

BÄTZING, W. (1996). Agricoltura nell'arco alpino: quale futuro? Milano: Franco Angeli, $400 \mathrm{p}$.

BÄTZING, W. (2005). Le Alpi: una regione unica al centro dell'Europa, Torino, Bollati Boringhieri, 485 p.

BÄTZING, W., PERLIK, M. and M. DEKLEVA (1996). "Urbanization and Depopulation in the Alps", Mountain Research and Development, vol. 16, no. 4, p. 335-350.

BECK, U. (1992). Risk Society: Towards a New Modernity, London, Sage, 272 p.

BONDONIO, P. V. (2007). A giochi fatti: le eredità di Torino 2006, Roma, Carocci, 376 p.

BRENNER, N. (1999). "Globalisation as Reterritorialisation: the Re-scaling of Urban Governance in the European Union”, Urban Studies, no. 36, p. 431-45I.

BULL, H. (1977). The Anarchical Society: A Study of Order in World Politics, Basingstoke, Palgrave, 335 p.

CARATTI DI VALFREI, P. and D. LANZETTA (2006). Sviluppo e tutela dell'ambiente attraverso i grandi eventi: il caso delle Olimpiadi Torino 2006, Bologna, II Mulino, 189 p.

CARDOSO, F. H. and E. FALETTO (1984). Dependéncia e desenvolvimento na América Latina: ensaio de interpretação, Rio de Janeiro, Zahar, nombre total de pages. 
CASTELLS, M. (2000). The Rise of the Network Society, Oxford, Blackwell Publishers, 594 p.

CASTELLS, M. (2002). "Local and Global: Cities in the Network Society”, Tijdschrift voor Economische en Sociale Geografe, vol. 93, no. 5, p. 548-558.

CASTRONOVO, V. and A. D'ORSI (1987). Torino, Roma, Laterza, $683 \mathrm{p}$.

Chambers, R. and G. R. CONWAY (I99I). "Sustainable rural livelihoods: practical concepts for the $\left.2\right|^{\text {st }}$ century”, IDS Discussion Paper, 296. London.

$\mathrm{CHURCH}$, J. M. and P. ANGELINI (Unpublished manuscript). Bolzano e la Convenzione delle Alpi. Ministero dell'Ambiente e della Tutela del Territorio e del Mare EURAC. Roma-Bolzano.

CLARK, W. C. (2007). "Sustainability Science: A Room of Its Own”, PNAS, 104, p. 1737-1738.

CLAYTON, A. M. H. and N. J. RADCLIFFE (1996). Sustainability: A Systems Approach, Boulder, CO, Westview Press, 224 p.

COLUCCIA, S. (2003). "Tra Roma e Bolzano, distandze ravvicinate (a colloquio con Paolo Angelini)", Academia, no. 33 , p. $45-46$.

CONVENTION ALPINE (2007). Report on the State of the Alps: Transport and Mobility in the Alps, Innsbruck, Secrétariat permanent.

CONVENTION ALPINE. Groupe De Travail Transports (2008). Mobilité durable dans les Alpes: bonnes pratiques et analyse du système de mobilité, Grenoble, Convention alpine, $15 \mathrm{p}$.

CONVENTION ALPINE. Groupe De Travail Transports (2009a). Mobilité touristique durable dans les Alpes, Paris, Convention alpine, $16 \mathrm{p}$.

CONVENTION ALPINE. Groupe De Travail Transports (2009b). Public transport accessibility of Alpine tourist resorts from major European origin regions and cities: synthesis report, Paris-Wien, Convention alpine, $100 \mathrm{p}$.

CONVENTION ALPINE. Groupe De Travail Transports. Sous-Groupe Coûts (2007). Les coûts réels des transports dans les corridors transalpins, Roma, Convention alpine, $33 \mathrm{p}$

COOPER, R. (2000). The Postmodern State and the World Order, London, Demos, 55 p.

DASGUPTA, P., CLARK, W. C., BONGAARTS, J., CARPENTER, S., KATES, R., OSTROM, E., SCHELLNHUBER, J. and B.L. TURNER II (Forthcoming). Sustainability Science: An Introduction.

DEBARBIEUX, B. (I995). Tourisme et montagne, Paris, Economica, $112 \mathrm{p}$.

DEBARBIEUX, B. (1999). "Figures combinées de la ville et de la montagne. Réflexion sur les catégories de la connaissance géographique", Revue de géographie alpine, vol. 87, no. I, p. 33-49.
DEBARBIEUX, B. (2002). "La traversée des Alpes: une histoire d'échelles et d'intérêts, d'épousailles et de divorces", Revue de géographie alpine, vol. 90, no. 3, p. II-24.

DEL BIAGGIO, C. (2009). "The institutionalization of the alpine region: an analysis based on a study of two panalpine networks (Alliance in the Alps and Alparc)", Revue de géographie alpine, vol. 97, no. 2, p. 99-II2.

DEMATTEIS, G. (197I). Città per le Alpi. Rivista della montagna, vol. 9, no. I, p. 2-9.

DEMATTEIS, G. (2009). "Polycentric urban regions in the Alpine space”, Urban Research \& Practice, vol. 2, no. I, p. 18-35.

EASTERLING, W. and C. POLSKY (2004). "Crossing the Divide: Linking Global and Local Scales in HumanEnvironment Systems" in SHEPPARD, E. S. and R. B. MCMASTER (Eds.) Scale and Geographic Inquiry: Nature, Society, and Method, Malden, MA, Blackwell, p. 66-85.

ETZIONI, A. (1993). The Spirit of Community: Rights, Responsibilities, and the Communitarian Agenda, New York, Crown Publishers, 323 p.

EUROPEAN COMMUNITIES (1985). The European Community and Its Regions: 10 Years of Community Regional Policy and of European Regional Development Fund (ERDF), Luxembourg, Office for Official Publications of the European Communities, $57 \mathrm{p}$.

FOUCAULT, M. (2004a). Naissance de la biopolitique: cours au collège de France (1978-1979), Paris, Gallimard, 356 p.

FOUCAULT, M. (2004b). Sécurité, territoire, population: cours au Collège de France (1977-1978), Paris, Seuil, 435 p.

FOURNY, M.-C., X. PIOLLE and F. TESSON (2004). "Logique d'acteurs et dynamiques d'action dans l'émergence d'un objet spatial 'réseau de villes': une coproduction géographique en trois tableaux" in B. DEBARBIEUX and M.-C. FOURNY (Eds.), L'effet géographique: construction sociale, appréhension cognitive et configuration matérielle des objets géographiques, Grenoble, Editions de la MSH, p. I4I-I60.

FUKUYAMA, F. (1992). The End of History and the Last Man, New York, Free Press, 464 p.

GAMBLE, A. (2007). "Regional Blocs, World Order and the New Medievalism" in M. Telò (Ed.), European Union and New Regionalism: Regional Actors and Global Governance in a Post-Hegemonic Era (2 ed.), Aldershot, Ashgate, p. 2I36.

GUERIN, J.-P. (1994). "Villes alpines en réseau: le sillon alpin", Les Dossiers de la revue de géographie alpine, vol. I3, p. 83

HARVEY, D. (1989). "From Managerialism to Entrepreneurialism: the Transformation of Urban Governance in Late Capitalism", Geographika Annaler, 7I-B, p. 3-I7.

HARVEY, D (2008). Géographie de la domination, Paris, Les Prairies ordinaires, $118 \mathrm{p}$. 
HESPANHA, A. M. (1986). As vésperas do Leviathan: instituções e poder político em Portugal, século XVII, Lisboa, Universidade Nova de Lisboa, 797 p.

HURRELL, A. (1995). "Regionalism in Theoretical Perspective" in L. FAWCETT and A. HURRELL (Eds.), Regionalism in World Politics: Regional Organization and International Order, Oxford, Oxford University Press, p. 37-73.

JESSOP, R. (1993). "Towards a Schumpeterian Workfare State? Preliminary Remarks on Post-Fordist Political Economy", Studies in Political Economy, vol. 40, p. 7-35.

JOUVE, B. and C. LEFÈVRE (Eds.). (2002). Local Power, Territory, and Institutions in European Metropolitan Regions, London, Routledge, $260 \mathrm{p}$.

KECKSTEIN, V. (1999). "Kleinstädte und Marktgemeinden zwischen Urbanität und Zersiedelung", Revue de géographie alpine, vol. 87, no. 2, p. 89-103.

KNOX, P. L. and P. J. TAYLOR (1995). World Cities in a World-System, Cambridge, Cambridge University Press, $348 \mathrm{p}$.

KRATOCHWIL, F. (1986). "Of Systems, Boundaries, and Territoriality: An Inquiry Into the Formation of the State System", World Politics, vol. 39, no. I, p. 27-52.

LATOUR, B. (1997). Nous n'avons jamais été modernes: essai d'anthropologie symétrique, Paris, La Découverte, 207 p.

LE BART, C. (1999). "Les Politiques d'image, entre marketing territorial et identité locale" in BALME, R., A. FAURE and A. MABILEAU (Eds.), Les Nouvelles Politiques locales dynamiques de l'action publique, Paris, Presses de Sciences Po, p. 4I5-427.

LefEBVRE, H. (199I). The Production of Space, Oxford, Basil Blackwell, $464 \mathrm{p}$

LIPSET, S. M. and S. ROKKAN (1967). Party systems and voter alignments: cross-national perspectives, New York, Free Press, $554 \mathrm{p}$.

MABILEAU, A. (1995). Le système local en France, Paris, LGDJ, 1995, $157 \mathrm{p}$.

MACCHIAVELLI, A. (2009). "Alpine Tourism", Revue de géographie alpine, vol. 97, no. I, p. 99-II0.

MAGALHÃES, J. R. (1993). "No alvorecer da modernidade (I480-I620)" in J. MATTOSO (Ed.), História de Portugal (Vol. 3), Lisboa, Círculo de Leitores, p. I49-I64 p.

MAGGI, M. and S. PIPERNO (2002). "Turin: The Vain Search For Gargantua" in B. JOUVE and C. LEFÈVRE (Eds.), Local Power, Territory, and Institutions in European Metropolitan Regions, London, Routledge, p. 175-195.

MANCEBO, F. (2006). Le développement durable, Paris, Colin, $269 \mathrm{p}$.

MANCEBO, F. (2007). “Des risques 'naturels' aux politiques urbaines à Mexico", Revue de géographie alpine, vol. 95, no. 2, p. 95-107.
MARTINA, A. (2006). Comunicare la città: il caso di Torino olimpica, Milano, Mondadori, 239 p.

MILLON-DELSOL, C. (1993). Le principe de subsidiarité, Paris, Presses universitaires de France, $127 \mathrm{p}$.

O'BRIEN, R. (1992). Global Financial Integration: the End of Geography, New York, Council on Foreign Relations Press, $120 \mathrm{p}$.

OLIVEIRA MARQUES, A.H. (1972). History of Portugal, Volume I: From Lusitania to Empire, New York, Columbia University Press, 507 p.

PAPANICOLOPULU, I. (2004). "The Secretariat of the Alpine Convention" in T. TREVES, L. PINESCHI and A. FODELLA (Eds.), Sustainable Development of Mountain Areas, Milano, Giuffré, p. 2I5-232.

PERLIK, M. (1999). "L'avenir des villes des Alpes en Europe", Revue de géographie alpine, vol. 87, no. 2, Reprinted from Geographica Bernensia, p. 9-2I.

PERLIK, M. and P. MESSERLI (2004). "Urban Strategies and Regional Development in the Alps", Mountain Research and Development, vol. 24, no. 3, p. 215-219.

PINSON, G. (2009). Gouverner par projet. Urbanisme et gouvernance des villes européennes. Paris: Presses de Sciences Po, 420 p.

RAFFESTIN, C. (1986). "Écogenèse territoriale et territorialité" in F. AURIAC and R. BRUNET (Eds.), Espaces, jeux et enjeux, Paris, Fayard - Fondation Diderot, p. 175-185.

RAFFESTIN, C. (2003). "Turin ou la capitale paradoxale" in B. LEVY and C. RAFFESTIN (Eds.), Voyage en ville d'Europe: géographies et littérature, Genève, Métropolis, p. $191-213$.

RISSE-LOBIS, S. (2003). EURAC: Una casa per l'Accademia Europea di Bolzano, Wien, Folio Verlag, $96 \mathrm{p}$.

RUGGIE, J. G. (1993). "Territoriality and beyond: problematizing modernity in international relations", International Organization, vol. 47, no. I, p. 139-174.

SACHS, I. (2004). Desenvolvimento includente, sustentável, sustentado, Rio de Janeiro, Garamond, I55 p.

SACHS, I. and O. LEPAGE (1997). L'écodéveloppement: stratégies pour le XXle siècle, Paris, Syros, $122 \mathrm{p}$.

SASSEN, S. (2006). Territory, Authority, Rights: From Medieval to Global Assemblages, Princeton, NJ, Princeton University Press, $5 \mathrm{I} 2 \mathrm{p}$.

SAVITCH, H. and P. KANTOR (2002). Cities in the International Marketplace: The Political Economy of Urban Development in North America and Western Europe, Princeton, Princeton University Press, 449 p.

SCHOLTE, J. (2000). Globalization: A Critical Introduction, New York, Palgrave MacMillan, 384 p.

SCOTT, A. (1998). Regions and the World Economy: The Coming Shape of Global Production, Competition and Political Order, Oxford, Oxford University Press, 192 p. 
SERGI, G. (Ed.) (1997). Storia di Torino, Torino, Einaudi, I024 p.

TALBOT, R. B. (1977). The European Community's Regional Fund: A Study in the Politics of Redistribution, Oxford, Pergamon Press, $280 \mathrm{p}$.

TILLY, C. (1998). "International Communities: Secure and Otherwise" in E. ADLER and M. BARNETT (Eds.), Security Communities, Cambridge, Cambridge University Press, p. 397-4I2.

TOOHEY, K. and A. J. VEAL (2000). The Olympic Games: A Social Science Perspective, Walingford, CABI, 224 p.

TORRICELLI, G. P. (1993). "La ville dans les Alpes: zone grise ou laboratoire pour les transports de demain? ", Revue de géographie alpine, vol. 81, no. 4, p. 37-62.

TORRICELLI, G. P. (1998). “Urbanizzazione e mobilità nell'arco centrale: verso un'estensione metropolitana selettiva" in G. SCARAMELLINI (Ed.), Montagne a confronto: Alpi e Appennini nella transizione attuale,Torino: Giappichelli, p. 175-198.

TURNER, B. L., W. C. CLARK, R. W. KATES, J. RICHARDS, J. T. MATHEWS and W. MEYER (1993). The Earth as Transformed by Human Action: Global and Regional Changes in the Biosphere over the Past 300 Years", Cambridge, Cambridge University Press, 732 p.

VELTZ, P. (2008). Des lieux et des liens. Essai sur les politiques du territoire à l'heure de la mondialisation, La Tour d'Aigues, Éditions de l'Aube, 155 p.

VEYRET-VERNIER, G. (1969). "Playdoyer pour les moyennes et petites villes. Revue de géographie alpine", vol. 57, no. I, p. 5-24.

VEYRET-VERNIER, G. (1970). "Essai de définition et de classification des petites villes", Revue de géographie alpine, vol. 58, no. I, p. 5I-66.

VEYRET, P. and G. VEYRET (1964). "Petites et moyennes villes des Alpes", Revue de géographie alpine, vol. 52, no. I, p. 5-I24.

VV.AA. (2008). Inconvenient Truths: Get Ready to Rethink What It Means to Be Green. Wired, 16(6).

WALLERSTEIN, I. M. (1974). The Modern World-System: Capitalist Agriculture and the Origins of the European World-Economy in the Sixteenth Century, New York, Academic Press, 410 p.

WALLERSTEIN, I. M. (1980). The Modern World-System: Mercantilism and the Consolidation of the European WorldEconomy, 1600-I750, New York, Academic Press, 388 p.

WALLERSTEIN, I. M. (2004). The Modern World-System in the Longue Durée, Boulder, CO, Paradigm, 248 p.

WORLD COMMISSION ON ENVIRONMENT AND DEVELOPMENT (1987). Our Common Future, Oxford, Oxford University Press. 